\title{
Erosivity factor in the Universal Soil Loss Equation estimated from Finnish rainfall data
}

\author{
MAXIMILIAN POSCH and SePPo REKolainen \\ Posch, M. \& Rekolainen, S. 1993. Erosivity factor in the Universal Soil Loss \\ Equation estimated from Finnish rainfall data. Agric. Sci. Finl. 2: 271-279. (Water \\ and Environment Research Institute, FIN-00101 Helsinki, Finland.) \\ Continuous rainfall data recorded for many years at 8 stations in Finland were used to \\ estimate rainfall erosivity, a quantity needed for soil loss predictions with the Universal \\ Soil Loss Equation (USLE). The obtained erosivity values were then used to determine \\ the 2 parameters of a power-law function describing the relationship between daily \\ precipitation and erosivity. This function is of importance in erosion modeling at \\ locations where no breakpoint rainfall data are available. The parameters of the power- \\ law were estimated both by linear regression of the log-transformed data and by \\ non-linear least-square fitting of the original data. Results indicate a considerable \\ seasonal (monthly) variation of the erosivity, whereas the spatial variation over Finland \\ is rather small.
}

Key words: precipitation, erosivity, USLE, Finland

\section{Introduction}

Rainfall is an important factor causing soil erosion in Finland. The terminal velocity of falling raindrops determines the kinetic energy for the detachment of soil particles. Early measurements of the terminal raindrop velocity were carried out by LENARD (1904) and SCHMIDT (1909). More refined measurements, using electric equipment, have been made by LAWS (1941) and GUNN and KINZER (1949). A high degree of correlation between drop size, and therefore terminal velocity, and rainfall intensity was found by LAWS and PARSONS (1943). The effect of rainfall intensity on soil detachment was formulated mathematically by WISCHMEIER and SMITH (1958) and connected to soil loss prediction by WISCHMEIER and SMITH (1978).

Several agricultural transport models, such as CREAMS (KNISEL 1980), its later extension
GLEAMS (LEONARD et al. 1987) and EPIC (WILLIMAS et al. 1984), use the Universal Soil Loss Equation (USLE, WISCHMEIER and SMITH 1978) or its modifications for erosion calculations. The USLE contains a rainfall factor, which is based on the rainfall kinetic energy derived from breakpoint rainfall data (i.e. individual storms). However, in many cases breakpoint data are not available. Some models, such as CREAMS, provide an option to use daily rainfall amounts as input data to the model. In this case the rainfall factor is computed with a power-law relating daily precipitation to rainfall erosivity. This power-law has been derived from breakpoint data by LOMBARDI (1979). However, the parameters of this relationship are not universal, they depend on the geographical location and on the time of the year. The spatial dependence of the parameters of the power-law has been investigated by RICHARDSON et al. (1983) and HAITH and MER- 
RILL (1987) for several locations in the United States. The influence of the resolution of the rainfall data on the erosivity calculations has been studied by WILLIAMS and SHERIDAN (1991).

The objective of this study was to estimate the parameters for the rainfall factor used in the USLE for each month of the warm season from breakpoint rainfall data collected at 8 stations in Finland.

\section{Rainfall data}

Continuous rainfall records from 8 stations (Fig. 1) were analyzed in this study for estimating the para-

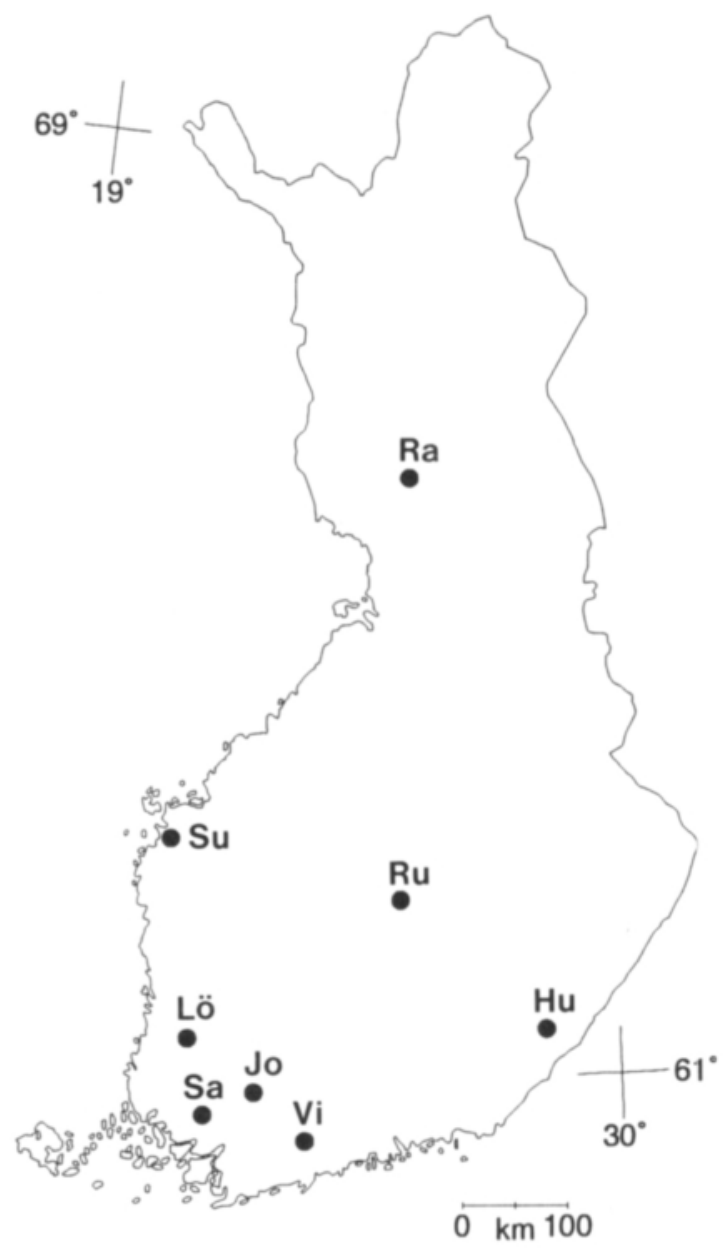

Fig. 1. Location of the 8 stations with continuous rainfall measurements analyzed in this paper. meters for the rainfall factor used in the USLE. Seven of these stations are operated by the Water and Environment Research Institute and one - in Jokioinen - by the Finnish Meteorological Institute. The location and the number of years of record are given in Table 1.

All rainfall gauges (pluviographs) used by the Water and Environment Research Institute have a Wild-type collector $\left(500 \mathrm{~cm}^{2}\right.$ collector area with a Nipher-type windshield) with the opening $1.5 \mathrm{~m}$ above ground. The rainfall gauges are not protected against frost, and they are in operation only from the end of April to the beginning of November (depending on the location). In the northernmost station of Ranua frost and snowfall frequently occur in May and October, and therefore the number of observations in these months is low. The device draws the graph for one week on a single sheet of paper. The resolution of these graphs is about 15 minutes and about $0.1 \mathrm{~mm}$. A more detailed description of the equipment is given in PosCH et al. (1992).

The pluviograph used by the Finnish Meteorological Institute in Jokioinen is a Belford-type collector $\left(378 \mathrm{~cm}^{2}\right.$ ellipsoidal opening) with no windshield and $1.5 \mathrm{~m}$ above ground. The device is in operation throughout the year, and the protection against frost is maintained with $\mathrm{NaCl}$. The pluviograms are drawn on a chart on a daily basis. The minimum resolution for rainfall depth is about $0.1 \mathrm{~mm}$, but due to the daily basis of the chart the time resolution is better compared to the weekly charts used at the other stations.

Table 1. Name, location and years of record of the rainfall stations used in this study.

\begin{tabular}{|c|c|c|c|c|}
\hline \multirow[t]{2}{*}{ Station } & \multicolumn{2}{|c|}{ Location } & \multirow{2}{*}{$\begin{array}{l}\text { Height } \\
\text { m a.s.l. }\end{array}$} & \multirow{2}{*}{$\begin{array}{l}\text { Years of } \\
\text { record }\end{array}$} \\
\hline & $\mathrm{E}$ & $\mathrm{N}$ & & \\
\hline Jokioinen & $23^{\circ} 30^{\prime}$ & $60^{\circ} 49^{\prime}$ & 104 & $1966-1990$ \\
\hline Vihti & $24^{\circ} 26^{\prime}$ & $60^{\circ} 25^{\prime}$ & 65 & $1964-1990$ \\
\hline Ranua & $26^{\circ} 05^{\prime}$ & $66^{\circ} 10^{\prime}$ & 185 & $1976-1990$ \\
\hline Savijoki & $22^{\circ} 38^{\prime}$ & $60^{\circ} 36^{\prime}$ & 54 & $1972-1990$ \\
\hline Löytäneenoja & $22^{\circ} 16^{\prime}$ & $61^{\circ} 15^{\prime}$ & 40 & $1964-1990$ \\
\hline Ruunapuro* & $26^{\circ} 02^{\prime}$ & $62^{\circ} 31^{\prime}$ & 105 & $1963-1990$ \\
\hline Sulvanjoki & $21^{\circ} 41^{\prime}$ & $62^{\circ} 58^{\prime}$ & 15 & $1963-1990$ \\
\hline Huhtisuonoja & $28^{\circ} 41^{\prime}$ & $61^{\circ} 24^{\prime}$ & 112 & $1963-1990$ \\
\hline
\end{tabular}

* Data for $1964,1966,1968,1988$ and 1989 is skipped due to malfunction of the sampling device. 
The graphs have been digitized and combined to obtain the cumulative rainfall data for every summer half year, ranging from May to October. Rainfall events in April and November were included in the Jokioinen data, since most of the rainfall still comes as water during those months. The winter months (December-March) were skipped in this study because of the high probability of snowfall.

Due to the resolution of the equipment $2.4 \mathrm{~mm}$ $\mathrm{d}^{-1}=0.1 \mathrm{~mm} \mathrm{~h}^{-1}$ was selected as the minimum depth and 15 minutes as a minimum duration of a rainfall event. In addition, $180 \mathrm{~min}$ was chosen as the minimum length of a gap separating two events (see PosCH et al. 1992).

\section{Estimation of rainfall erosivity}

The equation for computing rainfall energy $\mathrm{E}$, for rainfall given by a continuous function in time $t$, is

$$
\text { (1) } \quad E=\int_{0}^{T} e(t) i(t) d t
$$

where $e$ is the rainfall energy per unit rainfall, $i$ is the rainfall intensity for the time differential dt and $\mathrm{T}$ is the duration of the rainfall. With $\Delta \mathrm{t}_{\mathrm{k}}$ as the $\mathrm{k}$-th part of the storm pluviogram for which a constant rainfall intensity $i_{k}$ can be assumed, Eq. 1 can be written in the discrete form

$$
\text { (2) } E=\sum_{k=1}^{p} e_{k} i_{k} \Delta t_{k}
$$

where $e_{k}$ is the rainfall energy per unit rainfall for the $k$-th increment and $p$ the number of increments.

The unit energy $e_{k}$ itself is a function of the intensity and, according to a regression equation by WiSCHMEIER and SMITH $(1958,1978)$, it is given by

$$
e= \begin{cases}916+331 \log _{10} i & \text { for } i \leq 3 \text { in } / h \\ 1047 & \text { for } i>3 \text { in } / h\end{cases}
$$

where the unit energy e has units of foot-tonsf/acreinch and the intensity $\mathrm{i}$ is expressed in in/h (tonsf stands for ton force). US units are used here for simplicity and the conversion to SI units is given below. Eq. 3 is based on rain drop size and terminal velocity measurements, and it is independent of the geographical location (LAWS and PARSON 1943, GUNN and KINZER 1949).

According to WISCHMEIER and SMITH (1958), the best single variable to predict rainfall erosivity of a single rainfall event is the product of the total rainfall energy $\mathrm{E}$ and its maximum 30 -minute intensity $\mathbf{I}_{30}$, i.e.

$$
\mathrm{EI}=\mathrm{E} \cdot \mathrm{I} 30
$$

and it is the quantity EI which enters the soil loss calculations with the USLE. Since no data correlating soil loss and rainfall erosivity is available for Finland, Eq.4 is also used in this study.

Since breakpoint rainfall data is not always available, LOMBARDI (1979) (see also RICHARDSON et al. 1983) presented a simple power-law linking daily precipitation amount $\mathrm{z}$ and rainfall erosivity EI:

$$
\text { (5) } \quad \mathrm{EI}=\mathrm{az} \mathrm{b}^{\mathrm{b}}
$$

In the USLE EI has to be in units of (100 fttonsf/acre)(in/h), and values of $a=8.0$ and $b=1.51$ were derived by regression analysis from 2700 data points from the United States, and these values are also coded in the CREAMS model.

The breakpoint rainfall data for the 8 stations described in the previous section has been used for computing both the rainfall erosivity and the daily rainfall depth. Rainfall events of less than 30 minutes duration have been omitted, since a 30 minute maximum intensity $\mathrm{I}_{30}$ cannot be computed for these events. Rainfall events extending over midnight were split into separate events with one ending at midnight, the other one starting at midnight; but the 30 minute maximum intensity of the whole event has been used for both. Furthermore to be consistent with the derivation of the original equations - storms of less than 0.5 inch and separated from the previous rainfall by more than 6 hours have not been included in the computations, unless as much as 0.25 inch of rain fell in 15 minutes. Those rainfall events, i.e. non-intensive rain falling on dry soil, are reported to have only small erosive effect (WISCHMEIER and SMITH 1978). For the 8 Finnish stations treated in this 
paper this amounts to skipping $70-75 \%$ of the recorded rainfall events; however, it does not mean that all rainfalls below 0.5 inches are skipped (see also Fig. 2).
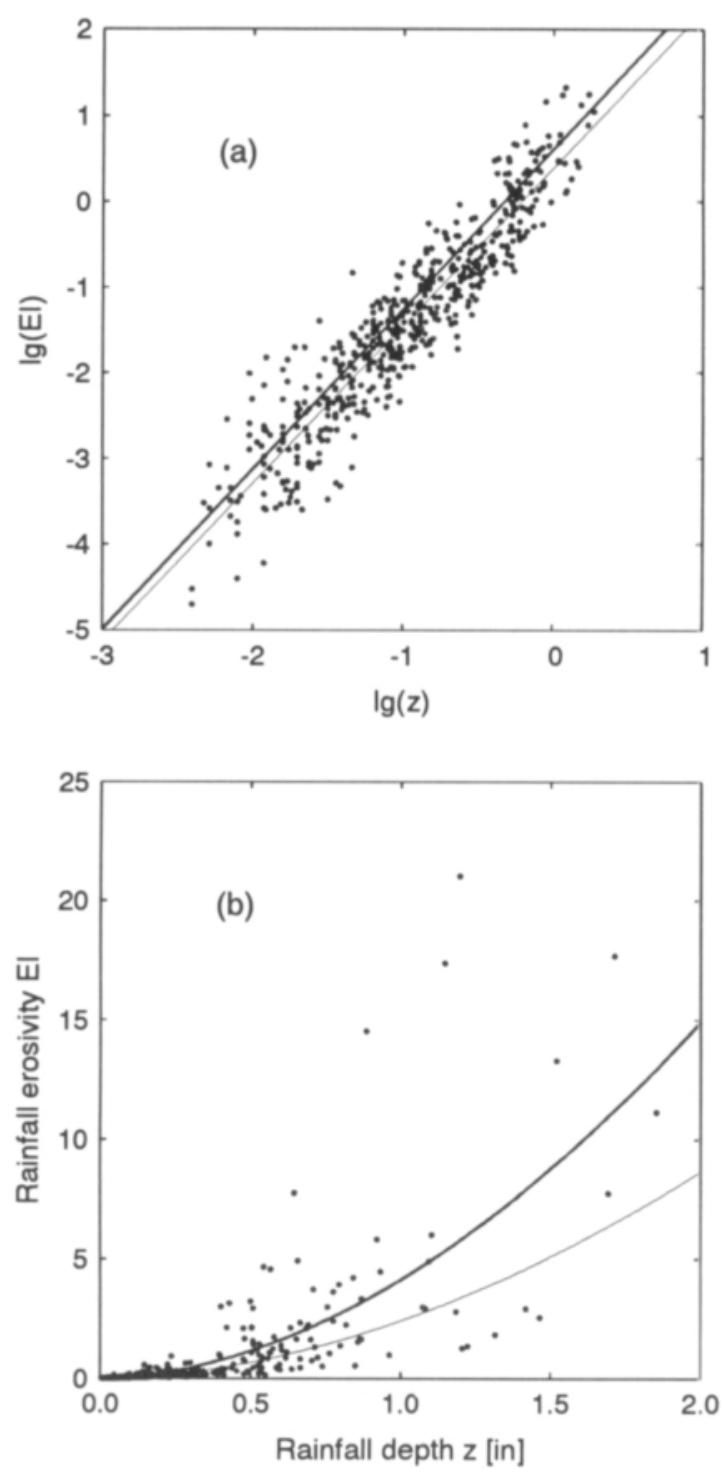

Fig. 2. Rainfall erosivity EI $[(100 \mathrm{ft}$-tonsf/acre $)(\mathrm{in} / \mathrm{h})]$ as a function of daily rainfall amount [in] in Jokioinen (a) in double-logarithmic scale, (b) in normal scale. The thin line shows the least-square fit obtained by linear regression of the log-transformed data, and the thick line shows the leastsquare fit obtained by non-linear regression on the original data.
We assume that Eq.3 for computing unit rainfall energy also holds for Finland. Then the rainfall erosivity of a single storm is computed via Eq.4, and the daily rainfall erosivity is obtained by summing the erosivities of the individual rainfall events:

$$
\text { (6) } \mathrm{EI}=\sum_{\mathrm{i}=1}^{\mathrm{n}} \mathrm{EI}_{\mathrm{i}}
$$

where $\mathrm{EI}_{\mathrm{i}}$ is the erosivity of the $\mathrm{i}$-th storm and $\mathrm{n}$ is the number of rainfall events on that day. The daily erosivity values obtained in this way, together with the corresponding daily precipitation values, are then used to estimate the parameters $\mathrm{a}$ and $\mathrm{b}$ in Eq.5.

Following customary procedures, we first logtransformed the data (both $\mathrm{z}$ and EI) and estimated $\lg (\mathrm{a})$ and $\mathrm{b}$ by linear regression. This yielded highly significant correlations ( $r>0.90$ in all cases; see Table 2 and Fig. 2a). Due to the logarithmic transformation the parameter values obtained in this way emphasize small values and the influence of the more important but fewer high values is not reflected in the shape of the regression curve (see thin line in Fig. 2b).

Therefore, also a non-linear least-square minimization algorithm was employed for estimating the parameters a and $b$. The algorithm chosen is the so-called Levenberg-Marquardt method (PRESS et al. 1986). This method minimizes

$$
\chi^{2}(a, b)=\sum_{i=1}^{N}\left(E I_{i}-a z_{i}^{b}\right)^{2}
$$

where $\mathrm{N}$ is the number of observations. As an example, the parameters obtained with this method for Jokioinen were used to plot the erosivity function in Fig. 2 (thick line). As can be seen, the resulting curves clearly differ from the one with parameters obtained by linear regression when plotted untransformed (Fig. 2b), whereas the logtransformed plot (Fig. 2a) would suggest that there is not much difference.

Most erosion models, such as CREAMS, have been developed in the United States and have incorporated the USLE formulated in the original US units. To facilitate comparison we present our re- 
Table 2. Number of storms n, erosivity parameters $a_{\text {lin }}$ and $b_{\text {lin }}$, estimated by linear regression from the log-transformed rainfall depth $\mathrm{z}$ and rainfall erosivity EI, and erosivity parameters a and b estimated by non-linear least square fit from the original data for the 8 rainfall stations for each month and the whole observation period. Also shown are the correlation coefficients $\mathrm{r}_{\text {lin }}$ for the log-transformed data and the correlation coefficient $r$ for the untransformed data.

\begin{tabular}{|c|c|c|c|c|c|c|c|}
\hline & $\mathrm{n}$ & $a_{\text {lin }}$ & $\mathbf{b}_{\text {lin }}$ & $n_{\text {in }}$ & a & b & $\mathrm{r}$ \\
\hline \multicolumn{8}{|c|}{ Jokioinen: } \\
\hline Apr & 65 & 0.83 & 1.61 & 0.94 & 0.65 & 1.37 & 0.90 \\
\hline May & 40 & 2.62 & 1.85 & 0.93 & 2.95 & 1.51 & 0.74 \\
\hline Jun & 40 & 3.36 & 1.86 & 0.93 & 5.09 & 1.53 & 0.59 \\
\hline Jul & 68 & 3.93 & 1.78 & 0.95 & 5.27 & 2.20 & 0.81 \\
\hline Aug & 69 & 4.06 & 1.86 & 0.95 & 3.98 & 1.30 & 0.71 \\
\hline Sep & 73 & 2.02 & 1.67 & 0.93 & 3.06 & 1.62 & 0.72 \\
\hline Oct & 79 & 1.55 & 1.71 & 0.93 & 2.45 & 2.12 & 0.82 \\
\hline Nov & 120 & 1.08 & 1.70 & 0.93 & 0.99 & 1.49 & 0.87 \\
\hline ALL & 554 & 2.42 & 1.84 & 0.93 & 4.14 & 1.85 & 0.69 \\
\hline \multicolumn{8}{|l|}{ Vihti: } \\
\hline May & 60 & 1.27 & 1.68 & 0.92 & 1.09 & 1.29 & 0.68 \\
\hline Jun & 46 & 2.16 & 1.79 & 0.94 & 2.46 & 1.19 & 0.52 \\
\hline Jul & 81 & 2.59 & 1.76 & 0.95 & 4.50 & 3.28 & 0.73 \\
\hline Aug & 93 & 2.89 & 1.80 & 0.94 & 2.69 & 1.06 & 0.71 \\
\hline Sep & 108 & 1.83 & 1.66 & 0.93 & 2.33 & 1.31 & 0.65 \\
\hline Oct & 95 & 0.94 & 1.54 & 0.94 & 1.51 & 2.47 & 0.77 \\
\hline ALL & 498 & 1.93 & 1.73 & 0.93 & 2.54 & 1.42 & 0.69 \\
\hline \multicolumn{8}{|l|}{ Ranua: } \\
\hline May & 44 & 1.03 & 1.58 & 0.95 & 0.98 & 1.52 & 0.88 \\
\hline Jun & 47 & 1.43 & 1.52 & 0.93 & 1.70 & 1.28 & 0.80 \\
\hline Jul & 47 & 1.85 & 1.67 & 0.95 & 1.34 & 0.84 & 0.74 \\
\hline Aug & 53 & 1.64 & 1.60 & 0.92 & 1.47 & 0.79 & 0.55 \\
\hline Sep & 45 & 1.16 & 1.75 & 0.93 & 1.33 & 1.56 & 0.83 \\
\hline Oct & 19 & 0.81 & 1.62 & 0.96 & 0.84 & 1.68 & 0.93 \\
\hline ALL & 255 & 1.44 & 1.66 & 0.94 & 1.39 & 1.09 & 0.69 \\
\hline \multicolumn{8}{|c|}{ Savijoki: } \\
\hline May & 59 & 1.11 & 1.62 & 0.95 & 0.79 & 1.29 & 0.86 \\
\hline Jun & 58 & 2.01 & 1.73 & 0.94 & 3.64 & 1.65 & 0.62 \\
\hline Jul & 75 & 2.87 & 1.82 & 0.97 & 3.40 & 1.53 & 0.78 \\
\hline Aug & 79 & 3.37 & 1.74 & 0.95 & 3.97 & 1.30 & 0.64 \\
\hline Sep & 63 & 1.39 & 1.65 & 0.93 & 2.10 & 2.81 & 0.80 \\
\hline Oct & 48 & 0.87 & 1.54 & 0.94 & 1.01 & 1.50 & 0.79 \\
\hline ALL & 382 & 2.12 & 1.75 & 0.95 & 3.26 & 1.65 & 0.68 \\
\hline \multicolumn{8}{|c|}{ Löytäneenoja: } \\
\hline May & 73 & 1.31 & 1.68 & 0.92 & 1.88 & 1.12 & 0.56 \\
\hline Jun & 55 & 2.91 & 1.88 & 0.93 & 3.56 & 1.60 & 0.77 \\
\hline Jul & 73 & 2.43 & 1.70 & 0.93 & 2.92 & 1.29 & 0.74 \\
\hline Aug & 77 & 3.65 & 1.94 & 0.95 & 3.99 & 1.42 & 0.69 \\
\hline Sep & 98 & 2.48 & 1.82 & 0.95 & 5.24 & 2.06 & 0.61 \\
\hline Oct & 52 & 0.67 & 1.48 & 0.91 & 1.00 & 1.49 & 0.59 \\
\hline ALL & 430 & 2.24 & 1.79 & 0.93 & 3.52 & 1.59 & 0.67 \\
\hline \multicolumn{8}{|c|}{ Ruunapuro: } \\
\hline May & 43 & 2.29 & 1.79 & 0.94 & - & - & 0.56 \\
\hline Jun & 60 & 2.20 & 1.73 & 0.94 & 6.73 & 3.30 & 0.75 \\
\hline Jul & 77 & 4.09 & 1.84 & 0.95 & 4.50 & 2.10 & 0.71 \\
\hline Aug & 92 & 3.27 & 1.82 & 0.92 & 4.84 & 2.34 & 0.69 \\
\hline Sep & 111 & 1.80 & 1.69 & 0.95 & 2.08 & 1.26 & 0.57 \\
\hline Oct & 59 & 0.78 & 1.53 & 0.94 & 0.82 & 1.53 & 0.90 \\
\hline ALL & 444 & 2.41 & 1.77 & 0.94 & 4.21 & 2.44 & 0.64 \\
\hline \multicolumn{8}{|c|}{ Sulvajoki: } \\
\hline May & 80 & 1.60 & 1.75 & 0.93 & 1.29 & 1.46 & 0.78 \\
\hline Jun & 52 & 3.39 & 1.91 & 0.97 & 5.38 & 3.07 & 0.77 \\
\hline Jul & 79 & 4.66 & 1.88 & 0.95 & 7.17 & 2.19 & 0.68 \\
\hline Aug & 85 & 4.50 & 1.87 & 0.95 & 3.97 & 0.94 & 0.82 \\
\hline Sep & 117 & 2.35 & 1.75 & 0.94 & 3.00 & 1.54 & 0.77 \\
\hline Oct & 62 & 1.36 & 1.62 & 0.94 & 2.25 & 2.17 & 0.87 \\
\hline ALL & 479 & 2.98 & 1.83 & 0.95 & 4.91 & 1.31 & 0.66 \\
\hline \multicolumn{8}{|c|}{ Huhtisuonoja: } \\
\hline May & 70 & 1.64 & 1.70 & 0.94 & 1.40 & 1.43 & 0.70 \\
\hline Jun & 63 & 2.33 & 1.73 & 0.96 & 3.43 & 1.03 & 0.65 \\
\hline Jul & 76 & 4.60 & 1.98 & 0.96 & 4.43 & 1.81 & 0.92 \\
\hline Aug & 100 & 3.59 & 1.80 & 0.95 & 3.91 & 1.31 & 0.79 \\
\hline Sep & 128 & 2.29 & 1.78 & 0.95 & 2.68 & 1.62 & 0.81 \\
\hline Oct & 91 & 1.10 & 1.56 & 0.95 & 1.17 & 1.51 & 0.86 \\
\hline ALL & 530 & 2.53 & 1.79 & 0.95 & 3.43 & 1.97 & 0.75 \\
\hline
\end{tabular}

Note: The dash '--' means that the data did not allow non-linear estimation of the erosivity parameters. 
sults in the same units. However, because of the gradual adoption of SI metric units also in the United States, we shall present the factors for converting the rainfall erosivity EI to the metric system.

Indicating the use of metric units by the subscript $\mathrm{m}$, Eq.5 reads:

$$
\mathrm{EI}_{\mathrm{m}}=\mathrm{a}_{\mathrm{m}} \mathrm{z}_{\mathrm{m}} \mathrm{b}_{\mathrm{m}}
$$

The conversion between US units and metric units is carried out by appropriate factors, i.e.

$$
\text { (9) } \mathrm{Z}_{\mathrm{m}}=\alpha \mathrm{z} \text { and } \mathrm{EI}_{\mathrm{m}}=\beta \mathrm{EI} \text {. }
$$

Expressing the rainfall depth in $\mathrm{mm}$ we get $\alpha=25.4$; to convert EI, expressed in (100fttonsf/acre)(in/h), to the metric unit of $(\mathrm{MJ} / \mathrm{ha})$ $(\mathrm{mm} / \mathrm{h})$ yields a conversion factor of $\beta=17.02$ (FosTER et al. 1981). Inserting Eq.9 into Eq. 8 gives the following formulae for $\mathrm{b}_{\mathrm{m}}$ and $\mathrm{a}_{\mathrm{m}}$ :

$$
\mathrm{b}_{\mathrm{m}}=\mathrm{b} \quad \text { and } \quad \mathrm{a}_{\mathrm{m}}=\frac{17.02}{25.4^{\mathrm{b}}} \mathrm{a}
$$

\section{Results and discussion}

The breakpoint rainfall data of the 8 stations described above have been used to estimate the rainfall erosivity parameters a and b in Eq.5 by regressing the daily rainfall amounts with the erosivity computed by Eqs.2-4, and results both for the linear and non-linear regression are presented in Table 2. This was done separately for each month and the whole observation period at each station.

The parameters alin and $b_{\text {lin }}$ were obtained by linear regression of the log-transformed data, showing high positive correlation ( $r>0.90$ in all cases). The exponent $b_{\text {lin }}$ is spatially and seasonally rather uniform, varying from 1.48 to 1.94 . This is in good agreement with the value of 1.81 used in the CREAMS model and derived from US data (LOMBARDI 1979, RICHARDSON et al. 1983). The proportionality factors alin range from 0.67 to 4.66 in Finnish conditions, and are considerably lower than those obtained for US conditions (8.0 in the CREAMS model; see also RICHARDSON et al. 1983). This means that the functional dependence of the erosivity on the daily rainfall amount in Finland and the United Sates is very similar, whereas the absolute erosivity values are at least twice as high in the United States, implying the same amount of rain is more erosive there (more intense storms, i.e. "hard rains", DYLAN 1966).

As already pointed out in the previous section, taking logarithms of the data gives little weight to the (less frequent) high values, which are those of interest in erosivity estimations (see Fig. 2). Therefore we estimated the parameters a and b by minimizing the sum of the true squared distances, and the obtained values are reported in Table 2. As an example, the resulting erosivity functions (Eq.5) are displayed for each month in Jokioinen (Fig. 3a) and for the whole observation period for all stations in Fig. 3b. The exponents b are of the same magnitude as the ones obtained by linear regression ( $b_{\text {lin }}$ ), but more varying (0.79-3.30). The multipliers a are even more variable and range from 0.65 to 7.17 , and are generally higher than alin.

Tests with the CREAMS model adapted to Finnish conditions, using erosivity parameters derived from Finnish rainfall data, gave better results than using the US parameters (REKOLAINEN and POSCH 1993). Therefore, in this CREAMS version monthly values for the parameters a and $b$ can be input by the user, and this allows the application of this model in locations with different rainfall characteristics.

Regarding the seasonal variation of the parameters, it can be seen from Table 2 that the values for a are clearly higher during the summer months (Jun-Aug) compared to May and the fall months (see Fig. 3a for Jokioinen). This seasonal variation is less pronounced for the exponents $b$. This implies that the storms during the summer months are more erosive, reflecting the higher intensity of convective storms, which occur more often during summer. The spatial variability in erosivity is small, with the exception of the northernmost station of Ranua, where the erosivity is lower than in the other stations (Fig. 3b), possibly due to less thunderstorms in Lapland (Atlas of Finland 1987). 

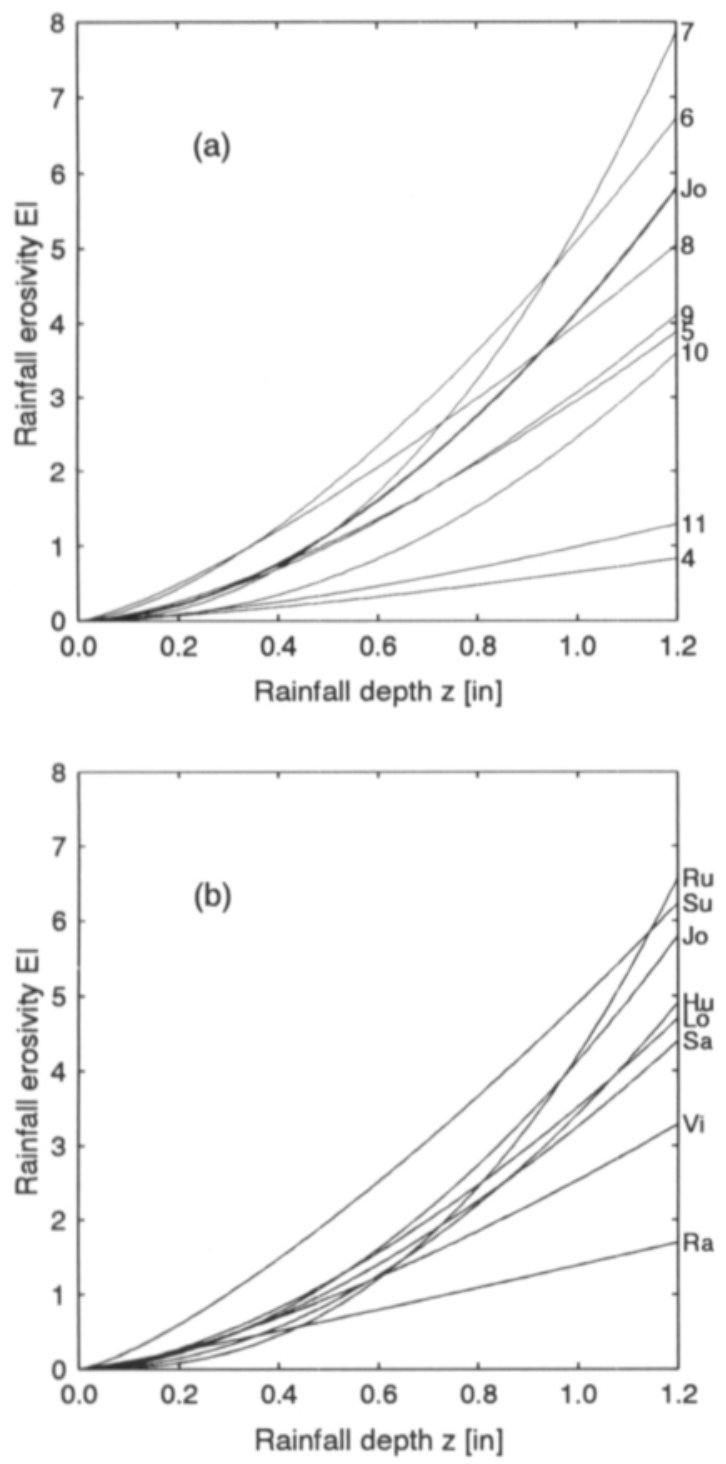

Fig. 3. Least-square fitted power-laws (see Eq.5) for computing daily rainfall erosivity EI [(100 ft-tonsf/acre)(in/h)] as a function of daily rainfall amount [in]. (a) for the months April-November (4-11) and the whole observation period (Jo; thick line) in Jokioinen, (b) for the whole observation period at the 8 stations.
Only a few data is available for April and November, and these indicate that erosivity is low in those months. No data is available for the winter months December to March, and in addition one would have to know if the precipitation falls as rain or snow in order to estimate their erosive impact. In Southern and Central Finland, where most of the agricultural fields are located, the proportion of snow as percentage of total precipitation varies from 30 to $40 \%$ (Atlas of Finland 1987). However, it is not only the amount of snow which determines its erosive impact, but also the speed of thawing. These factors have to be taken into account when estimating the overall erosion in Finland.

Acknowledgments. The authors want to acknowledge Mr. Asko Tuominen, Head of the Meteorological Observatory in Jokioinen, for providing the rainfall records from Jokioinen, and Ms. Sonja Lundsten and Ms. Sari Rinnetmäki for digitizing the pluviograms. 


\section{References}

Atlas of Finland 1987. Folio 131: Climate, National Board of Survey and Geographical Society of Finland, Helsinki.

DYLAN, B. 1966. A hard rain's a-gonna fall. In: The Freewheelin', Columbia, New York.

Foster, G.R., McCool, D.K., Renard, K.G. \& MoldenHAUER, W.C. 1981. Conversion of the universal soil loss equation to SI metric units. Journal of Soil and Water Conservation 36: 355-359.

GunN, R. \& KINZER, G.D. 1949. The terminal velocity of fall for water droplets in stagnant air. J. Met. 6: 243-248.

Haith, D.A. \& MerRILL, D.E. 1987. Evaluation of a daily rainfall erosivity model. Transactions of the ASAE 30: 90-93.

KNISEL, W.G. (ed.) 1980. CREAMS: A field-scale model for chemicals, runoff, and erosion from agricultural management systems. U.S. Department of Agriculture. Conservation Research Report 26. 640 p.

LAws, J.O. 1941. Measurement of the fall velocity of waterdrops and raindrops. Trans. Amer. Geophys. Union 22: 709-721.

— \& PARsons, D.A. 1943. The relation of rain drop size to intensity. Trans. Amer. Geophys. Union 24: 452-459.

LeNARD, P. 1904. Über Regen. Meteor. Z. 21: 248-262.

Leonard, R.A., Knisel, W.G. \& StILl, D.A. 1987. GLEAMS: Groundwater loading effects of agricultural management systems. Transactions of the ASAE 30: 1403-1418.

LOMBARDI, F. 1979. Universal Soil Loss Equation, runoff erosivity factor, slope length exponent, and slope steepness exponent for individual storms. PhD Thesis, Purdue University, W. Lafayette, Indiana.

Posch, M., Rekolainen, S. \& Seuna, P. 1992. Analysis and stochastic generation of summer storms in Finland. Aqua Fennica 22: 111-127.
Press, W.H., Flannery, B.P., Teukolsky, S.A. \& Vetter. LING, W.T. 1986. Numerical Recipes - The Art of Scientific Computing. Cambridge UP, United Kingdom. 818 p.

Rekolainen, S. \& Posch, M. 1993. Adapting the CREAMS model for Finnish conditions. Nordic Hydrology 24 (in press).

Richardson, C.W., Foster, G.R. \& Wright, D.A. 1983. Estimation of erosion index from daily rainfall amount. Transactions of the ASAE 26: 153-157.

SchмidT, W. 1909. Eine unmittelbare Bestimmung der Fallgeschwindigkeit von Regentropfen. Sitz. Akad. Wiss. Wien. Mathem.-naturw. Klasse 118, 2A: 71-84.

Williams, J.R., Jones, C.A. \& Dyke, P.T. 1984. A modeling approach to determining the relationship between erosion and soil productivity. Transactions of the ASAE 27: 129144.

Williams, R.G. \& Sheridan, J.M. 1991. Effect of rainfall measurement time and depth resolution on EI calculation. Transactions of the ASAE 34: 402-406.

WischmeIER, W.H. \& SMITH, D.D. 1958. Rainfall energy and its relationship to soil loss. Trans. Amer. Geophys. Union 39: 285-291.

— \& Sмrтh, D.D. 1978. Predicting erosion rainfall losses, guide to conservation planning. U.S. Department of Agriculture, Handbook No. 537, 58 p.

\section{Manuscript received April 1993}

Maximilian Posch

Seppo Rekolainen

Water and Environment Research Institute

P.O.Box 250

FIN-00101 Helsinki, Finland 


\title{
SELOSTUS
}

\section{Sateen eroosiovoiman arviointi Suomessa}

\author{
MaXimilian POSCH ja SEPPO REKOlainen
}

Vesien- ja ympäristöntutkimuslaitos

Suomessa sade on tärkeä maa-aineksen eroosion aiheuttaja. Sateen eroosiovoima on yksi määräävistä kertoimista USLEyhtälössä (Universal Soil Loss Equation), joka formuloitiin laajaan havaintoaineistoon perustuen USA:ssa ja jota käytetään edelleen laajalti eroosion arvioinnissa. Sateen erosiivisyyskerroin USLE:ssa perustuu sateen kineettiseen energiaan, joka arvioidaan yksittäisten sadetapahtumien ominaisuuksien avulla. Tällaista sadanta-aineistoa ei ole kuitenkaan saatavilla yhtä laajasti kuin päivittäistä aineistoa. USLE:n ja siihen perustuvien lukuisten eroosiomallien laaja käyttö vaatiikin sateen erosiivisyyden arviointia päivittäisen sadantatiedon avulla.

Päivittäisen sadannan ja sateen eroosiovoiman välinen riippuvuus on kuvattu USA:ssa potenssiyhtälönä. Tämän potenssiyhtälön kertoimet eivăt ole yleismaailmallisia, vaan riippuvaisia maantieteellisestä sijainnista ja vuodenajasta. Tässä tutkimuksessa arvioitiin Suomessa kahdeksalla havaintoasemalla kerätyn jatkuvan sadanta-aineiston perusteella päivittäisen sadannan ja sateen eroosiovoiman välisen potenssiyhtälön kertoimet.
Potenssiyhtälön $\mathrm{EI}=\mathrm{az}^{\mathrm{b}}$, jossa $\mathrm{EI}$ on sateen eroosiovoima ja z on päivittäinen sademäärä, kertoimet estimoitiin logaritmimuunnetusta havaintoaineistosta lineaarisen regression sekä muuntamattomasta aineistosta epälineaarisen algoritmin avulla. Lineaarisesti estimoidun yhtälön eksponentin b havaittiin vastaavan hyvin USA:ssa havaittuja, mutta yhtälön kertoimen a todettiin olevan huomattavasti alhaisemman. Tämä viittaa siihen, että sateiden eroosiovoima on Suomessa selvästi pienempi kuin USA:ssa.

Potenssiyhtälön kertoimissa havaittiin selvää ajallista vaihtelua siten, että kesäkuukausien sateiden erosiivisyys oli selvästi muita kuukausia korkeampi. Tämä johtuu todennäköisesti konvektiivisten sateiden suuremmasta osuudesta kesällä muihin vuodenaikoihin verrattuna. Sen sijaan eri havaintoasemien välillä ei havaittu suuria eroja lukuunottamatta pohjoisinta, Ranualla sijatsevaa asemaa, missä sateiden erosiivisyys oli selvästi muita asemia pienempi. Tämä johtuu mahdollisesti ukkossateiden vähäisemmästä määrästä Lapissa Etelä- ja Keski-Suomeen verrattuna. 